
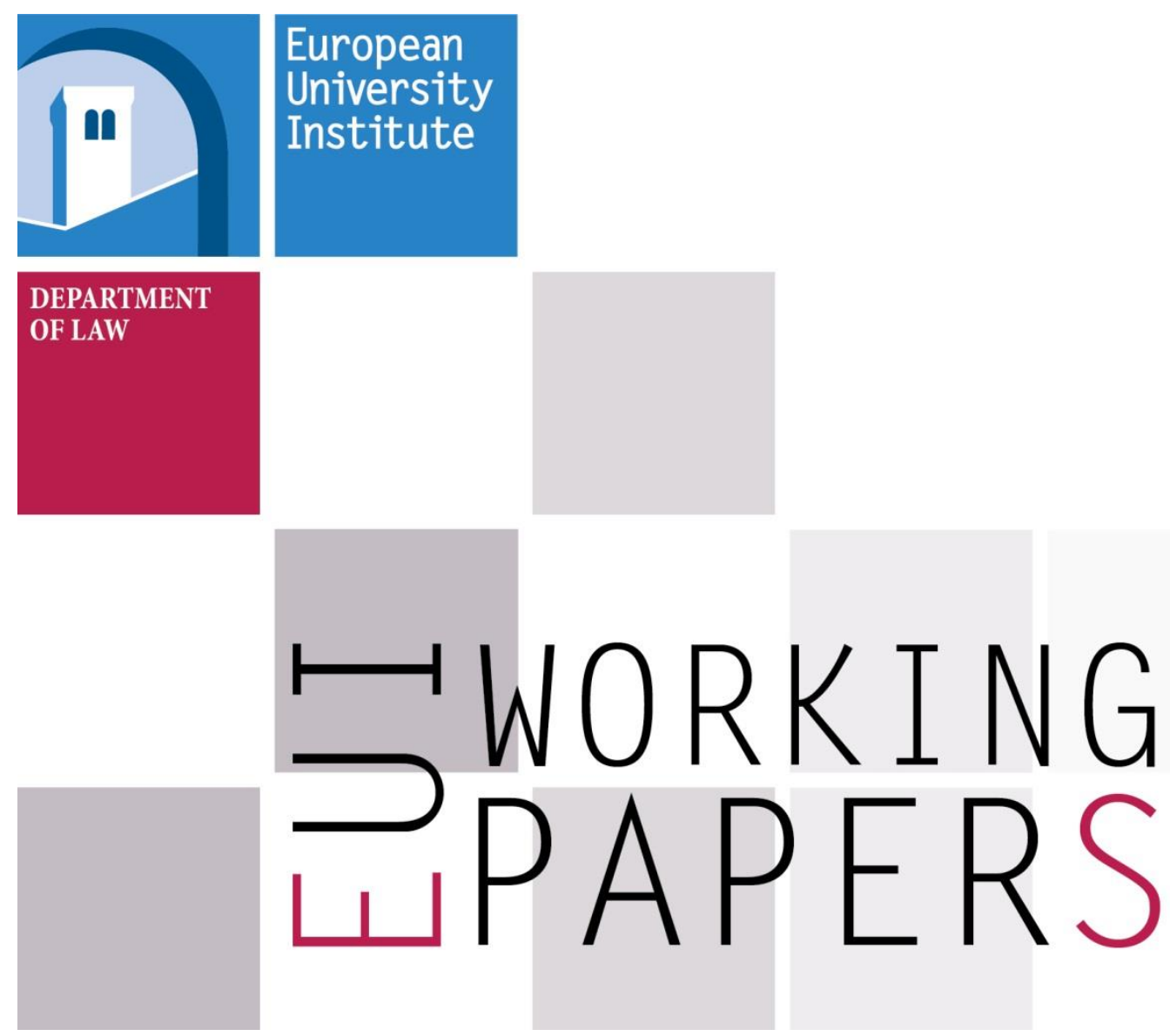

LAW 2015/08

Department of Law

Guiding the Exercise of Union's Administrative Power in the EU Wider Neighbourhood.

The Rule of Law from Paper to Operationalisation.

Ilaria Vianello 

European University Institute

Department of Law

GUIDING THE EXercise OF UNION'S ADMINISTRATIVE POWER IN THE EU WIDER NEIGHBOURHOOD.

THE RULE OF LAW FROM PAPER TO OPERATIONALISATION.

Ilaria Vianello

EUI Working Paper LAW 2015/08 
This text may be downloaded for personal research purposes only. Any additional reproduction for other purposes, whether in hard copy or electronically, requires the consent of the author(s), editor(s). If cited or quoted, reference should be made to the full name of the author(s), editor(s), the title, the working paper or other series, the year, and the publisher.

ISSN 1725-6739

(C) Ilaria Vianello, 2015

Printed in Italy

European University Institute

Badia Fiesolana

I-50014 San Domenico di Fiesole (FI)

Italy

www.eui.eu

cadmus.eui.eu 
Author's Contact Details

\section{Ilaria Vianello}

European University Institute

Law Department

Via Boccaccio 121

50133 Firenze, Italy

ilaria.vianello@eui.eu 


\begin{abstract}
The purpose of this paper is to establish that the Union is under an obligation to respect the rule of law when it acts externally, and second, to map out the outline of a research agenda on what exactly the rule of law might mean when operationalised in one field of EU external relations characterised by a wide variety of administrative activities i.e. the EU wider neighbourhood (Stabilisation and Association Process and European Neighbourhood Policy). Furthermore, the paper - throughout its development - will try to highlight that the power exercised by the administration in these two policies is significant and often carried out in an unregulated manner; thus the need to research the operationalisation of the rule of law in guiding the Union's administrative power in these two policies. The paper will proceed as follows. First, it will analyse the obligation to respect the rule of law when the Union acts externally. Secondly, it will provide the reader with a very brief definition of what it means to respect the rule of law in the EU internal legal order. Thirdly, it will explain the choice of the case study. Finally, by using as a starting point the meaning of the rule of law internally the paper will attempt to provide a preliminary operationalisation of what it means to respect the rule of law when the Union develops and implements its action in the wider neighbourhood.
\end{abstract}

\title{
Keywords
}

Rule of Law; EU External Action; EU Administrative Law; European Neighbourhood Policy; Stabilisation and Association Process. 


\section{Table of Contents}

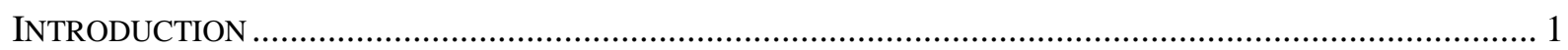

The CONSTITUTIONAL OBLIGATION TO RESPECT THE RULE OF LAW WHEN THE UNION ACTS



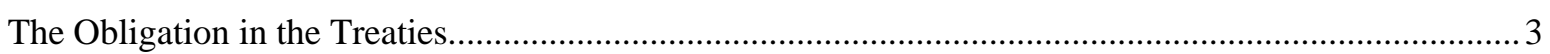

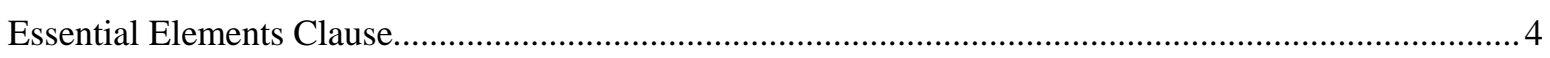

The Case Law of the Court of Justice of the European Union .................................................................... 4

RESPECTING THE RULE OF LAW IN THE EU INTERNAL LEGAL ORDER .................................................. 7

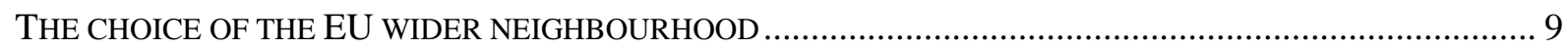



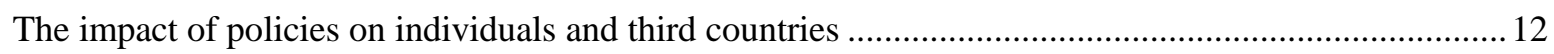

OPERATIONALISING THE RULE OF LAW IN THE EU WIDER NEIGHBOURHOOD CONTEXT ..................... 14

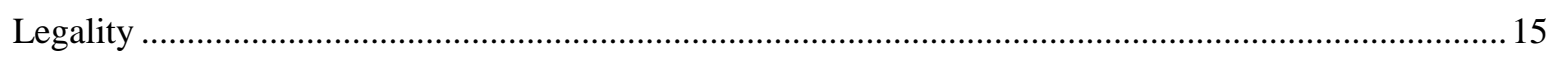

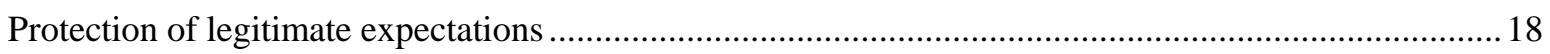

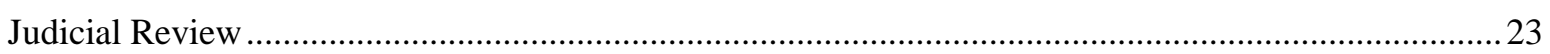

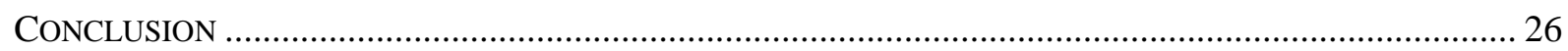





\section{Introduction}

The Union external action is no longer simply dominated by agreements regulated by international law; ${ }^{1}$ it is instead increasingly characterised by the proliferation of instruments produced by the Union's complex administrative machine. Substantially, these instruments mainly aim at assessing the development of third countries with which the Union has built ties and at determining the agenda of political and economic reform that these countries need to pursue in order to intensify their relations with the EU. While seemingly 'innocuous', these instruments create expectations and bear important legal consequences in respect of the position of individuals, of third countries, and of the Union as a whole. The power exercised by the administration of the Union in external relations is real; nevertheless, it finds itself in a general vacuum of clear norms. ${ }^{2}$ The administrative power is frequently exercised in a non-linear manner; in a discretionary fashion; and informally which is often the synonym of legally invisible. The Stabilisation and Association Process (SAP) ${ }^{3}$ and European Neighbourhood Policy (ENP) ${ }^{4}$ represent the most suitable example in order to describe this phenomenon. In this context the underlying legal question is the extent to which these processes collide with the respect of the rule of law.

The Treaty of Lisbon makes clear that the Union, when acting on the international scene, shall not only promote the principles that inspired its own creation - among which the rule of law - but shall also respect them in the development and implementation of its external action. If on the one hand this statement does not seem to cast doubts as to the legal obligation that the Union is required to respect, on the other it becomes essential to understand concretely what this general statement implies. Is it only a piece of wishful thinking? Is it just a nice statement showing that the Union aims at behaving like an exemplary normative actor in the world? If on the contrary this sentence is to be taken seriously a number of fundamental questions are in order: is this a constitutional obligation? If so,

${ }^{1}$ G. Bermann, 'The emergence of transatlantic regulation', in H. Hofmann and A. Türk (eds.), Legal Challenges in EU Administrative Law Towards and Integrated Administration (2009), 168-175; S. Cassese, 'What is Global Administrative Law and why study it?', in S. Cassese (eds.), Global Administrative Law: and Italian Perspective, Florence: RSCAS Policy Papers, 2012; S. Lavenex, 'EU External Governance in wider Europe', Journal of European Public Policy, 11:4, 680-700; S. Duke and S. Vanhoonacker, 'Administrative governance and CFSP', in H. Hofmann and A. Türk (eds.), EU Administrative Governance (2006), 361-387; D. Thym, 'Foreign Affairs', in A. von Bogdandy and J. Bast (eds.), Principles of European Constitutional Law (2009), 309, at 31; H. Hofmann, 'Transnational and Trans-Territorial RuleMaking A Basic Framework', Law Working Paper Series, Paper No. 2014-01; R. Wessel and J. Wouters, 'The Phenomenon of Multilevel Regulation: Interactions between Global, EU and National Regulatory Spheres: Towards a Research Agenda', in R. Wessel and J. Wouters (eds.), Multilevel Regulation and the EU: The Interplay between Global, European and National Normative Processes (2008), 9-47.

2 'Altogether the external competences of the institutions and bodies of the EU/EC require more attention from EU law and administrative law expert communities than has been granted thus far.' H.C.H. Hofman and A.H. Türk: Legal Challenges in EU Administrative Law: Towards an Integrated Administration, Edward Elgar Publishing, Glos, 2009.

${ }^{3}$ The SAP is a Union's regional approach initiated by the Commission in 1999 in order to assist the Western Balkan countries in meeting the relevant EU accession criteria and ultimately be accepted as official candidate for membership. The Western Balkan states include: Albania, Croatia, Bosnia and Herzegovina, Macedonia, Montenegro, Serbia and Kosovo. Croatia, however, is not any more a state taking part in the SAP since on the $1^{\text {st }}$ July 2013 become the $28^{\text {th }}$ member of the European Union. For more information on the policy see: S. Blockmans, Tough Love: The European Union's Relations with the Western Balkans (2007), 241-307.

${ }^{4}$ The European Union officially launched its ENP in 2003, with the objective of avoiding the emergence of new dividing lines between the enlarged EU and our neighbours and instead strengthening the prosperity, stability and security of all. This ENP framework is proposed to the 16 of EU's closest neighbours Algeria, Armenia, Azerbaijan, Belarus, Egypt, Georgia, Israel, Jordan, Lebanon, Libya, Moldova, Morocco, Palestine, Syria, Tunisia and Ukraine. For more information on the policy see: M. Cremona, 'The European Neighbourhood Policy More than a Partnership?' in M. Cremona (eds.), Developments in EU External Relations Law (2008), 245-299. 
what does it mean to respect the rule of law when the Union acts externally? Does the rule of law change meaning when operationalised in the EU external domain? What are the means to enforce it? Is it possible to state that the current regulatory framework respects the rule of law?

The purpose of this paper is to establish that the Union is under an obligation to respect the rule of law when it acts externally, and second, to map out the outline of a research agenda on what exactly the rule of law might mean when operationalised in one field of EU external relations characterised by a wide variety of administrative activities i.e. the EU wider neighbourhood (SAP and ENP). Furthermore, the paper - throughout its development - will try to highlight that the power exercised by the administration in these two policies is significant and often carried out in an unregulated manner; thus the need to research the operationalisation of the rule of law in guiding the Union's administrative power in these two policies. The paper will proceed as follows. First, it will analyse the obligation to respect the rule of law when the Union acts externally. Secondly, it will provide the reader with a very brief definition of what it means to respect the rule of law in the EU internal legal order. Thirdly, it will explain the choice of the case study. Finally, by using as a starting point the meaning of the rule of law internally the paper will attempt to provide a preliminary operationalisation of what it means to respect the rule of law when the Union develops and implements its action in the wider neighbourhood. 


\section{The Constitutional Obligation to Respect the Rule of Law when the Union acts Externally}

In order to determine whether we can talk of the rule of law as a constitutional principle guiding the external relation of the Union, the argument will proceed as follows. The first part will look at the meaning of the new Lisbon Treaty articles which make a clear reference to the rule of law in the context of external relations of the Union; secondly, it will show how the obligation to respect the rule of law when the Union acts externally is also present in the agreements between the Union and third countries; and finally, by using the Court of Justice of the European Union (CJEU) case law, it will stress how the rule of law is a constitutional principle that needs to be respected internally as well as externally.

\section{The Obligation in the Treaties}

The Treaties of the European Union seem to be rather straight forward in establishing the obligation for the Union to respect the rule of law when acting externally. The most significant articles will be hereby analysed.

Article 3(5) TEU: 'In its relations with the wider world, the Union shall uphold and promote its values and interests and contribute to the protection of its citizens [...].' [emphasis added]

The values to which article 3(5) TEU refers to are the one listed in article 2 (i.e. human dignity, freedom, democracy, equality, the rule of law and respect for human rights, etc.). The Union under this article is not only required to promote the rule of law; but is also required to uphold it in its relation to the wider world. Even if it is easy to denigrate such idealistic ambition, yet it is a fundamental Treaty provision formulated in mandatory terms: shall uphold. ${ }^{5}$

Article 21(3) TEU is probably the most significant article. The principles to which the article refers to are the one listed in paragraph 1 of the same article (i.e. democracy, the rule of law, the universality and indivisibility of human rights and fundamental freedoms, etc.).

Article 21(3) TEU: '3. The Union shall respect the principles and pursue the objectives set out in paragraphs 1 and 2 in the development and implementation of the different areas of the Union's external action covered by this Title and by Part Five of the Treat'. [emphasis added]

Differently from article 3(5) TEU, article 21(3) TEU uses the term principles as contrary to values. Even if it is doubtful that those responsible for the terminological variation between 'values' and 'principles' in the Treaties intended to introduce a theoretical distinction, it is still remarkable that while in article 2 TEU the rule of law is defined as a value; in article 21 TEU is defined as a principle. Values have a more indeterminate configuration and can be seen as part of the cultural patrimony or common heritage of Europe; whereas legal principles possess a more defined structure which makes them more suitable for the creation of legal rules. ${ }^{6}$ Most importantly, article 21(3) makes a clear link between the respect of the principles and the development and implementation of the Union's external action. Again, also in this article the provision is formulated in mandatory terms: shall respect.

The respect of the rule of law, in the development and implementation of the different areas of Union external action, is not only a principle that limits the action of the Union; it is also an objective.

\footnotetext{
${ }^{5}$ P. Eeckout, 'A normative basis for EU external relations? Protecting internal values beyond the Single Market', University College London, Working Paper Series.

${ }^{6}$ L. Pech, 'A Union Founded on the Rule of Law: Meaning and Reality of the Rule of Law as a Constitutional Principle of EU Law', European Constitutional Law Review, Volume 6, Issue 3, 2010, 359, at 366; M. Fernandez Esteban, The Rule of Law in the European Constitution (1999), 40-41.
} 
The Union according to article 21(2) TEU 'shall define and pursue common policies and actions, and shall work for a high degree of cooperation in all fields of international relations, in order to':

Article 21(2)(b) TEU: 'consolidate and support democracy, the rule of law, human rights and the principles of international law.' [emphasis added]

Article 21(2)(h) TEU: 'promote international system based on stronger multilateral cooperation and good global governance ${ }^{7}$.' [emphasis added]

The fact that the rule of law is also an objective that the Union needs to pursue in its relation to the outer world simply strengthens the claim that the Union needs to respect the rule of law when interacting with third states in order to meet the objective that it has set for itself. The conjunction of objectives and principles does not undermine the distinction between the rule of law as a principle and as an objective to be pursued. ${ }^{8}$

Finally, for the purpose of this paper it is important to highlight that the rule of law is also a founding value at the basis of its relations with its neighbours.

Article 8(1) TEU: 'The Union shall develop a special relationship with neighbouring countries, aiming to establish an area of prosperity and good neighbourliness, founded on the values of the Union and characterised by close and peaceful relations based on cooperation'. [emphasis added]

\section{Essential Elements Clause}

Next to the Treaty articles analysed, another important article needs to be highlighted. The latter takes the name of essential elements clause and is found in virtually all the agreements concluded by the EU with third countries (and for sure with its neighbours). The article makes clear that the rule of law is not only an essential element of the agreement but (most importantly for the analysis at stake) a principle at the basis of the external policies of the parties. The article below is an example of an essential elements clause, taken from the agreement between the EU and Serbia.

'Respect for democratic principles and human rights [...], respect for principles of international law, including full cooperation with the International Criminal Tribunal for the former Yugoslavia (ICTY), and the rule of law as well as the principles of market economy [...] shall form the basis of the domestic and external policies of the Parties and constitute essential elements of this Agreement.'

\section{The Case Law of the Court of Justice of the European Union}

There seems to be wide spread consensus among scholars that the rule of law has increasingly become an overarching and primary principle of Union constitutional law. ${ }^{9}$ Van Bogdandy concludes in his

7 'Good global governance from a legal perspective has been increasingly the subject of research of the new emerging Global Administrative Law projects which is in its essence a rule of law project: it aims to constitutionalize transnational public administration by general legal principles of administrative law rooted deeply in the rule of law.' F. Schuppert, 'New Modes of Governance and the Rule of Law', in M. Zürn, A. Nollkaemper, and R. Peerenboom (eds.), Rule of Law Dynamics: In an Era of International and Transnational Governance (2012), 90, at 103.

${ }^{8}$ A. Von Bogdandy, 'Founding Principles of EU Law: A Theoretical and Doctrinal Sketch', European Law Journal, Vol. 16, No. 2, 2010, 95, at 107.

${ }^{9}$ For an in depth discussion on the Rule of Law as constitutional principle please see: L. Pech, 'A Union Founded on the Rule of Law: Meaning and Reality of the Rule of Law as a Constitutional Principle of EU Law', European Constitutional Law Review, Volume 6, Issue 3, 2010, 359-396; L. Pech, 'The Rule of Law as a Constitutional Principle of the European Union', Jean Monnet Working Paper 04/09; E. Herlin-Karnell, 'EU values and the shaping of the international legal context', in D. Kochenov and F. Amtenbrink (eds.), The European Union's Shaping of the International Legal Order 
article on the founding principles of EU law that the 'values' listed in article 2 TEU - among which the rule of law - can be understood as 'constitutional principles and a constitutional legal discourse based thereon is viable both from a theoretical and technical legal point of view' ${ }^{10} \mathrm{~L}$. Pech who has also done extensive research on the rule of law as a constitutional principle of the EU is of the idea that article 2 TEU makes clear that the Union is 'founded on' the rule of law and that this is a foundational principle of constitutional value. ${ }^{11}$ In its very famous Les Verts judgment the CJEU already back in 1986 referred to the European Community as a 'a community based on the rule of law ${ }^{12}$ to the extent that neither the Member States nor the Community's institutions could avoid review of the conformity of their acts with the Community's 'constitutional character'. ${ }^{13}$ Subsequently in its opinion 1/91, by contrasting the EEA agreement with the Community legal order, the Court stated:

'[...] the EEC Treaty, albeit concluded in the form of an international agreement, none the less constitutes the constitutional charter of a Community based on the rule of law. ${ }^{14}$ [emphasis added]

If the rule of law is to be understood as a legal principle having constitutional value in the EU polity, the latter should be uphold both to its actions having an external as well as an internal dimension. This assumption of legal unity of EU law can also be justified in light of the new growing importance of guaranteeing coherence in Union's action. ${ }^{15}$ With the entry into force of the Treaty of Lisbon significant emphasis has been put on the importance of guaranteeing consistency between Union's policies and activities. ${ }^{16}$ Therefore, guaranteeing coherence between the respect of the rule of law internally as well as externally seems to be in line with the new Lisbon Treaty focus. Next to coherence, a possible parallelism can be drawn with the 'principle of complementarity' suggested by Dashwood and Heliskoski in the context of exclusive and implied external competences. ${ }^{17}$ The internal and external action do not run in parallel with each other, on the contrary, they complement each other. ${ }^{18}$ The respect of the rule of law in developing and implementing the Union's external action

(Contd.)

(2014), 89-107; A. Von Bogdandy, 'Founding Principles of EU Law: A Theoretical and Doctrinal Sketch', European Law Journal, Vol. 16, No. 2, 2010, 95-111.

${ }^{10}$ A. Von Bogdandy, 'Founding Principles of EU Law: A Theoretical and Doctrinal Sketch', European Law Journal, Vol. 16, No. 2, 2010, 95, at 111 .

${ }^{11}$ L. Pech, 'The Rule of Law as a Constitutional Principle of the European Union', Jean Monnet Working Paper 04/09.

${ }^{12}$ Case 294/83 Les Verts v. Parliament [1986] ECR 1339, para. 23.

${ }^{13}$ L. Pech, 'A Union Founded on the Rule of Law: Meaning and Reality of the Rule of Law as a Constitutional Principle of EU Law', European Constitutional Law Review, Volume 6, Issue 3, 2010, 359, at 359.

${ }^{14}$ Opinion 1/91 Pursuant to article 228 of the EEC Treaty.

${ }^{15}$ A. Von Bogdandy, 'Founding Principles of EU Law: A Theoretical and Doctrinal Sketch', European Law Journal, Vol. 16, No. 2, 2010, 95, at 109.

${ }^{16}$ Some significant examples: article 7 TFEU 'The Union shall ensure consistency between its policies and activities, taking all of its objectives into account and in accordance with the principle of conferral of powers.'; article 13(1) TEU 'The Union shall have an institutional framework which shall aim to promote its values, advance its objectives, serve its interests, those of its citizens and those of the Member States, and ensure the consistency, effectiveness and continuity of its policies and actions.'; 21(3) TEU 'The Union shall ensure consistency between the different areas of its external action and between these and its other policies. The Council and the Commission, assisted by the High Representative of the Union for Foreign Affairs and Security Policy, shall ensure that consistency and shall cooperate to that effect.'; article 256(2)(3) TFEU '[...]Decisions given by the General Court under this paragraph may exceptionally be subject to review by the Court of Justice, under the conditions and within the limits laid down by the Statute, where there is a serious risk of the unity or consistency of Union law being affected. [...]Decisions given by the General Court on questions referred for a preliminary ruling may exceptionally be subject to review by the Court of Justice, under the conditions and within the limits laid down by the Statute, where there is a serious risk of the unity or consistency of Union law being affected.'

${ }^{17}$ A. Dashwood and J. Heliskoski, 'The Classic Authorities Revisited', in A. Dashwood and C. Hillion (eds.), The General Law of E.C. External Relations (2000), 3, at 13.

${ }^{18}$ The principle of complementarity has been recently affirmed by the CJEU in Case C-658/11 Parliament v Council. 
complements the role of the rule of law as a constitutional principle in the Union legal order. The respect of the rule of law externally shall be read on the grounds of unity, coherence, and complementarity of the Union legal order.

The CJEU seems to be of the same view. In both Kadi I and Kadi II the CJEU stressed the importance of reviewing any community measure in light of fundamental rights in order to ensure consistency with the expression 'a Community based on the rule of law'. The expression 'Union based on the rule of law' instead of 'Community based on the rule of law' was for the first time used in the $E \& F$ case. This new expression seems to reinforce the idea that the rule of law is a constitutional principle covering all actions of the Union legal order and not only the ones under the old Community pillar.

'[T]he European Union is based on the rule of law and the acts of its institutions are subject to review by the Court of their compatibility with $E \boldsymbol{U}$ law and, in particular, with the Treaty on the Functioning of the European Union and the general principles of law.' ${ }^{19}$ [emphasis added]

Finally, the CJEU in one of its recent cases reinforced the role of article 3(5) as obliging the Union to respect it when acting externally. The case states the following:

'Under Article 3(5) TEU, the European Union is to contribute to the strict observance and the development of international law. Consequently, when it adopts an act, it is bound to observe international law in its entirety, including customary international law, which is binding upon the institutions of the European Union.' ${ }^{20}$ [emphasis added]

If a parallelism can be drawn, we could argue that if under article 3(5) the European Union is required, when it adopts an act, to observe international law; then it is also required to respect the rule of law. If the CJEU could make the link between the Union's obligation to contribute to the strict observance and the development of international law and the Union's obligation to observe international law when adopting an act; it would be very difficult to argue that the same link could not be established under the same article between the Union obligation to uphold its values - as referred to in article 2 and the Union's obligation to respect them when adopting an act.

In light of these multiple references to the Union's obligation to respect the rule of law when acting externally, there can be little argument as to the uniform validity of the rule of law as a constitutional principle internally and externally. ${ }^{21}$ The reiteration in the Lisbon Treaty that the rule of law needs to be respected when the Union acts externally cannot remain without consequences. However, before talking about the operationalisation of the principle in external relations it is essential to understand the meaning of the rule of law. Even under the premise of uniform validity of the principle internally and externally, the question still arises as to whether this corresponds to a uniform operationalisation. ${ }^{22}$ In order to construct the features that the rule of law assumes externally it seems reasonable to use as a starting point the meaning that the rule of law has when operating internally in the EU legal order; i.e. between the EU institutions and Member States and the EU institutions and Union citizens. Therefore, before entering in the specificities of the case study, the next section summarises what it entails to respect the rule of law in the EU internal legal order.

\footnotetext{
${ }^{19}$ Case C-550/09 E \& F [2010] ECR I-6209, para. 44.

${ }^{20}$ Case C-336/10 Air transport Association of America v. Secretary of State for Energy and Climate Change [2011], para. 101.

${ }^{21}$ Eeckout in one of its recent pieces clearly stated ' $[\mathrm{t}] \mathrm{he} \mathrm{EU}$ is required to act externally according to its own constitutionally determined normative basisis: i.e. its values.' P. Eeckout, ' A normative basis for EU external relations? Protecting internal values beyond the Single Market', University College London, Working Paper Series; see also E. Herlin-Karnell, 'EU values and the shaping of the international legal context', in D. Kochenov and F. Amtenbrink (eds.), The European Union's Shaping of the International Legal Order (2014), 89, at 97.

${ }^{22}$ A. Von Bogdandy, 'Founding Principles of EU Law: A Theoretical and Doctrinal Sketch', European Law Journal, Vol. 16, No. 2, 2010, 95, at 109 .
} 


\section{Respecting the rule of law in the EU internal legal order}

The Union constitutes a polity governed by the rule of law; meaning that the exercise of public power is subject to or regulated by a set of legal limitations. The CJEU has been able over the years to Europeanize the rule of law by using as starting point the legal traditions of the Member States. ${ }^{23}$ When paraphrasing the famous Les Verts judgment it seems possible to state that the Community was said to comply with the rule of law because it allegedly offered a comprehensive set of legal remedies and procedures with the aim of ensuring that its institutions - including Member States - adopt measures in conformity with EU law; and that natural and legal persons are able to challenge (directly or indirectly) the legality of any act which affects their Community rights. ${ }^{24} \mathrm{~A}$ remarkable development of the Court's more recent case law lies in linking explicitly the rule of law to the respect by the Union's institutions of more substantive requirements i.e. general principles of EU law. ${ }^{25}$

'The European Community is a... Community based on the rule of law in which its institutions are subject to judicial review of the compatibility of its acts with the Treaty and with the general principles of law which include fundamental rights. ${ }^{, 26}$ [emphasis added]

The compatibility of Union's acts with general principles of law has been reinforced by Advocate General Sharpston in her opinion delivered on 16 December 2010 on the case Paul Miles and Others $v$ European Schools. In her opinion she clearly states that by upholding important principles of Community law the Community ensures that it remains one that is based on the rule of law. ${ }^{27}$ Along this line of thought, Tridimas talks about principles derived from the rule of law. These principles include: the protection of fundamental rights, equality, proportionality, legal certainty, the protection of legitimate expectations, and the right of defence. These principles are characterized by two important features. First, they have been derived by the CJEU from the fundamental premise that the Community legal order is based on the rule of law. Secondly, they have been derived by the CJEU primarily from the laws of the Member States and used by it to supplement and redefine the Treaties. ${ }^{28}$ The CFI in one case made explicit the existence of a relationship between the Member States general principles and the Union general principles. The Court in the case made the link in respect of the right of sound administration and the principle of judicial review as being:

'general principles that are observed in a state governed by the rule of law and are common to the constitutional traditions of the member states ${ }^{29}$ [emphasis added]

The rule of law in the Union legal order has progressively become a dominant organizational paradigm of constitutional value. At the EU level the rule of law can be defined as an umbrella principle from which more concrete substantive legal principles can be derived with the objective of

${ }^{23}$ T. Tridimas, The General Principles of EU Law (2006), at 5-6. A. Arnull, 'The Rule of Law in the European Union', in A. Arnull and D. Wincott (eds.), Accountability and Legitimacy in the European Union (2002), 239, at 254; D. Kochenov, 'The EU Rule of Law: Cutting Paths through Confusion', 2 Erasmus Law Review 5, 5-24.

${ }^{24}$ L. Pech, 'A Union Founded on the Rule of Law: Meaning and Reality of the Rule of Law as a Constitutional Principle of EU Law’, European Constitutional Law Review, Volume 6, Issue 3, 2010, 359, at 371.

${ }^{25}$ Compliance with general principles, including fundamental rights, goes back to Internationale Handelsgesellschaft. However, in that case the CJEU did not make an explicit link to the respect of the rule of law. See Case 11/70 International Handelsgesellschaft v. Einfuhr- und Vorratsstelle Getreide [1970] ECR 1125.

${ }^{26}$ UPA, judgment of 25 July 2002, [2002] ECR 1-6677.

27 'I respectfully applaud the Court's willingness, in Zwartveld, to have regard to the teleology of the Treaties and to insist on its jurisdiction to uphold important principles of Community law, thereby ensuring that the European Communities continued to be a 'Community based on the rule of law.' Opinion of Advocate General Sharpston delivered on 16 December 2010, Case C-196/09 Paul Miles and Others Robert Watson MacDonald v. European Schools, para. 71.

${ }^{28}$ T. Tridimas, The General Principles of EU Law (2006), 4-5.

${ }^{29}$ Case T-54/99 Max.mobil Telekommunikation [2002] ECR II-313, paras 48 and 57. 
limiting the exercise of public power. ${ }^{30}$ This definition of the rule of law will be used as a starting point in order to develop the features that the rule of law has when limiting the power of the administration when acting externally. For current purposes the next two sections will only focus on re-thinking the meaning of the rule of law as a principle to be upheld when the Union develops and implements its action in the wider neighbourhood.

${ }^{30}$ Comparative studies on the Member State's definition of the rule of law; and the recent Commission Communication on the rule of law offer a coherent definition to the one provided by the CJEU. L. Pech, 'The Rule of Law as a Constitutional Principle of the European Union', Jean Monnet Working Paper 04/09; R. Grote, 'Rule of Law, rechtsstaat and état de droit', in Starck (eds.), Constitutionalism, Universalism and Democracy: A Comparative Analysis (1999), 269, at 305; Krygier, 'Rule of law', in M. Rosenfeld and A. Sajò (eds.), The Oxford Handbook of Comparative Constitutional Law (2012), at 233. Communication from the Commission to the European Parliament and the Council, 'A new Framework to strengthen the Rule of Law', $\operatorname{COM(2014)158~final/2~and~its~respective~Annex~I.~}$ 


\section{The choice of the EU wider neighbourhood}

The SAP and ENP represent two exemplary case studies of how the respect of the rule of law becomes essential when the Union develops and implements its external action. The reasons are the following. Firstly, the Union administrative bodies exercise a real and unexplored power in the development and implementation of the two policies; and secondly, this same power has a significant impact on individuals and on the countries taking part in the SAP and ENP. These two aspects will be analysed in turn.

\section{The exercise of real and unexplored administrative power}

If we picture the decision making machinery of the SAP and the ENP as a cycle, on the left side of the cycle we have the instruments defining the primary political choice such as agreements, financial assistance regulations, council conclusions and exchange of letter; while on the right side of the cycle we have the instruments implementing the primary political choice such as progress reports, action plans, European Partnership, etc.

\section{Instruments defining the Primary

$$
\text { Political Choice: }
$$

- Agreements

- Council Conclusions

- Exchange of Letters

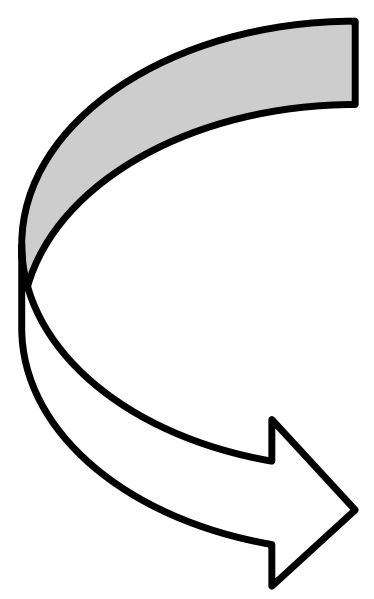

\section{Measures Implementing the Primary} Political Choice:

- Progress Reports

- Action Plans

- Strategy Paper

- Programming Documents

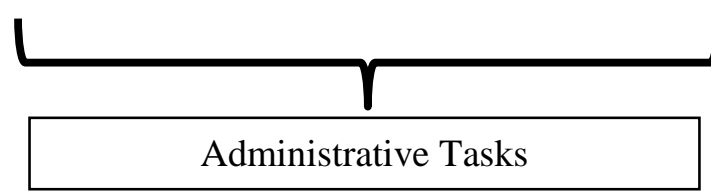


The activities standing on the right-hand side of the cycle have so far escaped an attentive analysis as to how they are drafted, or better, as to which principles should limit the power of the administration when drafting them. These instruments are administrative in nature: they are aimed at implementing the Union's primary political choice and they carry out administrative functions. ${ }^{31}$ They can be grouped in two categories.

The first group includes progress reports, ${ }^{32}$ action plans ${ }^{33}$ and European partnerships; ${ }^{34}$ the second group includes the activities linked to the financial cycle i.e. strategy papers and programming documents. The instruments of the first group have internal and external functions. Internally they have - to different degrees - preparatory, steering and interpretative function. Preparatory, because they are used as reference documents for further collaborative projects of the European Union with its neighbouring countries; steering because they lay down guidelines and priorities for EU engagement with the neighbours; and interpretative where they flesh out the scope and substance of the international agreements that bind the EU with its neighbours. ${ }^{35}$ Externally they have preparatory and rule-making functions. Preparatory insofar as they shall guide the third country in the transformation of general telos [e.g. membership or partnership] into more concrete individual acts applicable to single case situations. The key function of these instruments is to assist the addressee of the measure to evaluate a situation or circumstance and take appropriate action. The action suggested might be seen as constituting an invitation to the addressee to follow certain steps leading to - for example - the adoption of legislation or to the changing of their political agenda. For instance, progress reports and action plans are addressed to a specific third country and indicate quite clearly and in a detailed

31 They are aimed at supporting third countries in implementing the agreements they have concluded by the EU, and - most importantly - they are aimed at supporting the third countries to become members or stronger partners of the Union. They conduct administrative functions insofar as they act as monitoring, agenda setting, standard setting and implementing acts.

${ }^{32}$ The SAP progress reports are Commission working documents. The European Council invites the Commission to present the assessment of what each SAP country has achieved over the last year on preparing for EU membership. The reports briefly describe the relations between the EU and the SAP countries; they analyse the situation in each SAP country in terms of the political and economic criteria for membership; and they review the country's capacity to implement European standards (i.e. gradually approximate its legislation and policies with the acquis). The ENP progress reports are Joint Staff working documents between the Commission and the External Action Service (EEAS); before 2011 they were only Commission Staff working documents. The aim of these documents is to assess the progress made in the implementation, by each ENP country, on the priorities listed in their respective Action Plans.

${ }^{33}$ Action Plans are political documents laying down the strategic objectives of the cooperation between each ENP country and the EU. Their implementation helps fulfil the provisions of the agreements concluded by the EU with each ENP countries, build ties in new areas of cooperation. The elaboration of the Action Plains is in the hands of the Commission and - only recently - also of the EEAS. The draft action plans are presented by the Commission to the Council which swiftly endorse them as Council decision on the position to be adopted by the Communities and the Member States within each Council established by the agreements concluded by the Union and each ENP country. Once endorsed by the Council, the APs are subsequently presented to the respective Councils - established by the bilateral agreements - for approval. APs do not have legally binding effect on third countries (they are political documents), however they Council Decisions internally. C. Hillion, 'The EU's Neighbourhood Policy Towards Eastern Europe', in A. Dashwood and M. Maresceau (eds.), Law and Practice of EU External Relations (2008), 309, at 315.

${ }^{34}$ The European Partnerships (EPs) are Council decisions establishing the priorities for each of the SAP partners' differing situations. The EPs, even if adopted by the Council, are mainly the elaboration of the Commission who is at the forefront when it comes to the establishment of the priorities. Furthermore, the Commission is not bound to any negotiating mandate in its consultations with the SAP countries. The key role granted to the Commission in drafting these documents further reinforces its role in the pre-accession process. K. Inglis, 'The Pre-Accession Strategy and the Accession Partnerships', in A. Ott and K. Inglis (eds.), Handbook on European Enlargement: A Commentary on the Enlargement Process (2002), 103, at 108; . Kochenov, EU Enlargement and the Failure of Conditionality: Pre-accession Conditionality in the Fields of Democracy and the Rule of Law (2007), at 75.

${ }^{35}$ Van Vooren in his articles carries out a detailed analysis of the ENP action plans and how they fulfil all three functions. B. Van Vooren, 'A case-study of soft law in EU external relations: the European Neighbourhood Policy', European Law Review 2009, 34(5). 
manner what the third state has to do in order to intensify its relations with the Union. ${ }^{36}$ As such these measures may well constitute an initial step towards the realization or implementation of legally binding measures in the third state. ${ }^{37}$ In the moment in which they give rise to legally binging measures in the third states, we see clearly how they are also form of 'extra territorial' rule-making. Preparatory and rule-making activities arguably belong to some of the most influential areas of administrative activity. Decisions as to which standards should be applicable and which topic shall be put on the policy agenda, and in which order, can be expected to have a considerable impact on the final output. ${ }^{38}$ Finally, also externally, they might acquire interpretative function in the moment in which third countries' courts use these instruments to interpret the obligations present in the agreement that the EU has concluded with them. Externally action plans have also been used by courts as basis in order to justify their reference to the EU acquis for the interpretation of legal concepts and provisions transplanted from EU legislation. ${ }^{39}$

The instruments of the second group are strategy papers and programming documents. ${ }^{40}$ They determine the priorities for action towards meeting the objectives identified by the financial assistance regulation, ${ }^{41}$ the progress reports, the action plans, the European partnerships; ${ }^{42}$ and they indicate the

\footnotetext{
${ }^{36}$ For example the Action Plan with Georgia requires Georgia:
}

to hold local, parliamentary and presidential elections in accordance with international standards, through implementation of OSCE/ODIHR and Council of Europe recommendations.

to accede to the UN Convention on Corruption, and the relevant articles of UNTOC, to ratify the Council of Europe Criminal Law Convention on Corruption, to ensure that the domestic legislation is in line with the above mentioned international instruments, the Civil Law Convention on Corruption and the OECD Convention on combating bribery of Foreign Public Officials in International Business Transactions;

to continue work towards full implementation of the WTO Agreement on the Application of Sanitary and Phyto-sanitary measures and active participation in relevant international bodies (World Organisation for Animal Health (OIE), FAO/WHO/Codex Alimentarius, and IPPC/FAO after adhesion);

to draw up a first list of measures for gradual convergence towards EU general food safety principles and requirements (e.g. regulation 178/2002/EC; animal and plant or plant products identification and traceability systems; hygiene in food processing);

to give a proper consideration to the recommendations of the IMF/WB FSAP (Financial Sector Assessment Program) of 2006;

to complete the network of bilateral agreements between Georgia and EU Member States on avoidance of double taxation in line with the OECD Model Tax Convention;

to continue the reform of the Chamber of Control in line with the internationally accepted and EU best practice external audit standards (INTOSAI standards).

${ }^{37}$ This definition of preparatory acts is shaped around the meaning given by Hofmann, Rowe and Türk with regard of internal preparatory acts. H. C.H. Hofmann, G.C. Rowe and A.H. Türk, Administrative Law and Policy of the European Union (2013), at 546.

${ }^{38}$ T. Larsson and J. Trondal, 'Agenda setting in the European Commission: How the European Commission Structure and Influence the EU Agenda', in: H. C.H. Hofmann and A.H. Türk (eds), EU Administrative Governance (2006), 11-43.

${ }^{39}$ A. Khvorostiankina, 'Legislative approximation and application of EU law in Moldova', in P. Romanov and P. Van Elsuwege (eds.), Legislative Approximation and Application of EU Law in the Eastern Neighbourhood of the European Union, at. 174.

40 The Commission adoptes them in accordance with the examination procedure as outlined in article 5 Regulation (EU) No 182/2011 of the European Parliament and of the Council of 16 February 2011 laying down the rules and general principles concerning mechanisms for control by Member States of the Commission's exercise of implementing powers, OJ [2011] L55/13.

${ }^{41}$ Article 6 Regulation (EU) No. 231/2014 of the European Parliament and of the Council of 11 March 2014 establishing an instrument for Pre-accession Assistance (IPA II), OJ [2014] L77/13; article 7 Regulation (EU) No. 232/2014 of the European Parliament and of the Council of 11 March 2014 establishing a European Neighbourhood Instrument (ENI), OJ [2014] L77/30. 
activities that will be financed in order to achieve the chosen priorities. While seemingly technical, these two types of acts bear important discretionary powers. In particular, strategy papers and programming documents allow the Commission to identify which area will need support, to name a few: LGBT support, promotion of reconciliation, capacity-building measures for improving law enforcement, etc. Moreover, these instruments have the function of further supporting the transformation of the general telos of membership or partnership into concrete reforms. Thus, it can be stated that internally they have steering function; while externally preparatory.

The Union administration when drafting these documents - particularly the one of the first group finds itself in a general vacuum of norms; thus, frequently is left with not many options than acting in a discretionary and unregulated fashion. Few examples are of interest here. In the elaboration of the action plans the Commission was at the forefront in setting the priorities for action without any particular negotiating mandate and without really taking in consideration the opinion of the third country concerned. ${ }^{43}$ For example, in the case of the action plan concluded with Ukraine Hillion writes that 'the content of the drafts forwarded to the Ukrainian authorities, and the EU position during the "negotiations" were essentially the product of the Commission's own initiative' ${ }^{44}$ Another example of exercise of discretion is progress reports. Progress reports are the result of an ingenious work of the Commission. The Commission often found itself in the position to fill with content the criteria that it was required to monitor (e.g. public administration, rule of law, human rights, democracy, etc...) $)^{45}$ by drawing inspiration also from international sources (e.g. OECD). ${ }^{46}$ Moreover, it had to decide how to monitor compliance (e.g. 'enforcement strategy' vs 'governance of compliance strategy'); ${ }^{47}$ leaving open the question of why it chooses to use a specific strategy or to take precisely certain instruments in order to monitor compliance.

\section{The impact of policies on individuals and third countries}

The second reason that makes the SAP and the ENP such interesting case studies in analysing the operationalisation of the rule of law in the development and implementation of the Union external action is the impact that the administrative activities just described have on individuals and on the wider neighbourhood countries themselves. The impact on the position of individuals can be clearly sensed by the cases that arrived all the way to the $\mathrm{CJEU}^{48}$ in which individuals (especially from third

(Contd.)

${ }^{42}$ Article 4(1) Regulation (EU) No. 231/2014 of the European Parliament and of the Council of 11 March 2014 establishing an instrument for Pre-accession Assistance (IPA II), OJ [2014] L77/13; article 3(2) Regulation (EU) No. 232/2014 of the European Parliament and of the Council of 11 March 2014 establishing a European Neighbourhood Instrument (ENI), OJ [2014] L77/30.

${ }^{43}$ Since the Action Plans are non-binding instruments (they are adopted as recommendations) the legal requirements of the negotiating procedure of article 218 TFEU is by passed. M. Cremona, 'The European Neighbourhood Policy: More than a Partnership?' in M. Cremona (eds.), Developments in EU External Relations Law (2008), at 276.

${ }^{44}$ C. Hillion, 'The EU's Neighbourhood Policy Towards Eastern Europe', in A. Dashwood and M. Maresceau (eds.), Law and Practice of EU External Relations (2008), 309, at 315.

${ }^{45}$ D. Kochenov, EU Enlargement and the Failure of Conditionality: Pre-accession Conditionality in the Fields of Democracy and the Rule of Law (2007); 85 - 119; E. Tulmets, 'Experimentalist Governance in EU External Relations: Enlargement and the European Neighbourhood Policy', in C. F. Sabel and J. Zeitlin (eds.), Experimentalist Governance in the European Union Towards a New Architecture (2010), 297, at 312.

46 E.g. OECD (1999), "European Principles for Public Administration”, SIGMA Papers, No. 27, OECD Publishing. Available at: http://dx.doi.org/10.1787/5kml60zwdr7h-en (Consulted on 21.03.2014).

${ }^{47}$ M. Cremona, 'Introduction', in M. Cremona (eds.), Compliance and Enforcement of EU Law (2012).

${ }^{48}$ See cases: Case T-367/03 Yedaş Tarim ve Otomotiv Sanayi ve Ticaret AŞ v. Council of the European Union and Commission of the European Communities; Case T-346/03 Krikorian v. European Parliament, Council and Commission; Case T-2/04 Korkmaz v. Commission; Case T-292/09 Mugraby v. Council and Commission; Case C-581/11 P Mugraby v. Council and Commission. 
countries) challenged the action or in-action of the European Commission in developing and implementing its wider neighbourhood policy. The adoption of administrative instruments increases the predictability of how a certain policy will be implemented ${ }^{49}$ thus, the expectations of individuals increase as to the determination of the Union to enforce its policies. For example the Union made clear in a number of Commission communications that it has a clear conditionality policy according to which it will activate sanctions in case a third country fails to respect human rights. ${ }^{50}$ The adoption of this type of communications, as well as of progress reports indicating the failure on the side of the third country to respect human rights, increases the expectations of individuals, whose human rights are violated, that measures - like suspension of aid - will be taken by the Union in the moment in which their country violates human rights. Furthermore, the implementation of financial assistance can have a direct impact on the life of individuals.

The impact that the administrative activities have on the position of third countries is varied. First, they have an impact on how the relations between the Union and the third state develop. ${ }^{51}$ Second, progress reports and action plans have an undeniable standard setting function in as far as they are quite detailed as to which standard shall be used by the third country when passing legislation. Third, by determining which project shall receive financial support and by providing to the third country the list of priorities on which it shall focus, they have an undeniable impact on the third country's political agenda. ${ }^{52}$ Finally, if all these activities would come without consequences, how could we explain and justify the springing all over the neighbourhood states of think-tank and associations that have as one of their aims the review of the various progress reports and action plans that the Commission and the EEAS compile $?^{53}$

In light of the real and unexplored power exercised by the Union's administration in the two policies, and of the consequences that these two policies have on individuals and third countries, it becomes extremely important to inquire on how the administrative power is exercised in these two policies. The power granted to the Union administration in supervising and implementing the relationships between the Union with its neighbouring states should not be ignored or perceived as bad per se, it should rather be channelled by making sure that it respects the rule of law.

${ }^{49}$ H. C.H. Hofmann, G.C. Rowe and A.H. Türk, Administrative Law and Policy of the European Union (2013), at 536.

${ }^{50}$ Among others: Commission Communication on the inclusion of respect for democratic principles and human rights in agreements between the Community and third countries, COM (95) 216 final, 23.5.1995; Report from the Commission to the Council and the European Parliament on Common principles for future contractual relations with certain countries in South-Eastern Europe, $\operatorname{COM}(96) 476$ final, 2 October 1996; Commission Communication on the European Union's role in promoting human rights and democratisation in third countries, $\operatorname{COM}(2001) 252$ final 8.5.2001.

${ }^{51}$ For example the reports of the Commission shall inform whether to open accession negotiations or whether to sign a more comprehensive agreement with a neighbour state.

${ }^{52}$ Let's assume that the progress reports identify a lack of progress in the reform of the public administration, and the public administration reform is a key priority identified in either the action plans, or the European Partnerships. Consequently, the financial assistance strategy papers and planning documents - in line with the policy instruments - indicate that funds will be disbursed in order to support the public administration reform. The third country will, thus, find itself in a position to focus on the public administration reform if it would want to make use of the funding.

53 Some examples are the Inicijativa za monitoring europskih integracija $\mathrm{BiH}$ available at: http://eu-monitoring.ba/ (Consulted on 05.11.2014); Solidar Global Network available at: http://solidar.org/IMG/pdf/tunisia_v23.10.13_fr.pdf (Consulted on 05.11.2014); Al Hayar Center for Civil Society Development available at: http://www.hayatcenter.org/ (Consulted on 05.11.2014). 


\section{Operationalising the Rule of Law in the EU Wider Neighbourhood Context}

As summarised at the end of section 2, the rule of law internally is an organizational paradigm of constitutional value aimed at limiting the exercise of public power. The limits of the power are to be found in the law and in more substantive legal principles; and judicial review makes sure that the power stays within the defined boundaries. We have already seen in section 1 of the paper that the rule of law is a constitutional principle that needs to be respected when the Union acts in the outer world. Therefore, it is now in order to explore the legal limits aimed at fencing the exercise of public power when the Union acts in the EU wider neighbourhood.

In order to identify the most salient principles giving effect to the rule of law when the Union acts in the wider neighbourhood as well as their features, the following aspects need to be taken into consideration: the nature of the activities under analysis, the typology of activities at stake, ${ }^{54}$ and the specificities of the external domain. ${ }^{55}$ As just seen, the activities carried out by the Union in the SAP and ENP are administrative in nature. Thus, the first step in identifying the salient principles giving effect to the rule of law in the Union wider neighbourhood is to select those principles that are directly related to the administrative function. ${ }^{56}$ Some of the principles deriving from the rule of law have an impact primarily on legislative institutions; while others are aimed at the administrative function. The changing requirements and conditions for implementing EU policies have pushed the CJEU to develop, in parallel to the constitutional law principles, also administrative law specific principles aimed at giving effect to the rule of law. ${ }^{57}$

A narrow definition of the rule of law in administrative law terms implies that:

'administrative implementation occurs within the framework established by legislation, that subordinate legislation may be made by the administrative branch only where there is an enabling power in primary (Treaty) law or in European secondary legislation, and that such subordinate legislation must be within substantive limits and conform with procedural requirements of higher law. ${ }^{58}$

However, next to the strict definition of legality there are other elements of the principle of the rule of law which have achieved such a level of independence from the strict concept of legality that it is better to treat them on their own. Therefore, next to legality it seems important to choose another principle in order to start analysing the respect of the rule of law in the EU wider neighbourhood. The principle selected by this paper is the protection of legitimate expectations. The choice has been made since one of the recurring problems in the cases brought by individuals to the CJEU is the lack of action by the administration. Finally, since supervision gives substance to the rule of law, the ability by the court to review the action of the administration in the wider neighbourhood will be taken under analysis.

${ }^{54}$ M. Dawson, 'Soft Law and the Rule of Law in the European Union: Revision or Redundancy?' EUI Working Papers, RSCAS 2009/24.

55 'It should also be noted that, while sources of principles may themselves be identifiable, the exact specification of their content may not always be possible. Principles may often be merely indicative and, as a result, it may be possible to establish the exact scope of a particular principle only by identifying situations, practices, or rules which do or do not satisfy it. Even where a principle may have binding status, exactly what it demands in a specific situation may not always be apparent or easily identifiable, and may be controversial'. H. C.H. Hofmann, G.C. Rowe and A.H. Türk, Administrative Law and Policy of the European Union (2013), p. 145. M. Dawson, 'Soft Law and the Rule of Law in the European Union: Revision or Redundancy?', EUI Working Papers, RSCAS 2009/24, at 14.

56 'The rule of law tradition naturally fed into and informed development of EU Administrative law.' P. Craig, 'EU Administrative Law and Tradition', in M. Ruffert, Administrative Law in Europe: Between Common Principles and National Traditions (2013), 155, at 161.

${ }^{57}$ H. C.H. Hofmann, G.C. Rowe and A.H. Türk, Administrative Law and Policy of the European Union (2013), 143-145.

${ }^{58}$ H. C.H. Hofmann, G.C. Rowe and A.H. Türk, Administrative Law and Policy of the European Union (2013), at 150. 
Legality, protection of legitimate expectations and judicial review have their origins in national legal systems; they regulate the relation between the Member States authorities and the Union; and between the national or Union authorities and the persons under their jurisdiction. Binding the Union's external administrative action to the principles rooted in the rule of law requires analysing the principles in light of the challenges posed by their application in the EU wider neighbourhood. ${ }^{59}$ The necessity of possibly tuning the principles derived from the rule of law in light of the domain should not be seen as a heresy. In fact, principles giving effect to the rule of law can be understood as norms having a high degree of generality as to their content. They can be valid for a whole subject (e.g. contracts) or for a general branch of law (e.g. administrative law); but can also acquire sector specific connotations. ${ }^{60}$ The content of the rule of law is malleable. The core idea of the rule of law, limiting the exercise of public power, entails the potential to adjust to changing realities. ${ }^{61}$ The new suggested legal framework for the external relation's administrative activities is about using and adapting familiar European administrative law principles and rules in the admittedly less familiar setting of the Union's external relations. This new approach would imply that European administrative law would expand to the administrative regulation of a space differing from the traditional representation of the EUMember States and EU-citizens relations.

The next section by using as starting point the internal definition of legality, protection of legitimate expectations and judicial review aims at highlighting some of the distinctive features and some of the limits that legality, protection of legitimate expectation and judicial review acquire when applied to the domain of the EU wider neighbourhood. However, before starting, it is important to make two health warning. First, it is outside the scope of this paper to extensively describe each single principle; this is rather a preliminary attempt to start outlining their main possible operationalisation in one field of EU external action. Second, the next section - in discussing the CJEU case law - does not want to make a value judgment as to how the Court decided the cases; the cases are used as tools to show the difficulties in guaranteeing the protection of the rule of law under the current state of art.

\section{Legality}

The public administration must act under and within the law, whether as contained in primary and secondary legislation or in the jurisprudence of competent courts. This requirement includes a number of specific elements: acting within power; correct exercise of discretion; acting in conformity with legally mandated procedures - including e.g. the conduct of enquiries; and responding to justified individual claims. ${ }^{62}$ Does this principle maintain the same features when applied to the Union administration acting externally? This question is particularly relevant in light of the lack of a net of legally binding guidelines fencing the action of the administration in the SAP and ENP. In the absence of legally mandated procedures and clear delimitating boundaries, the Commission and the EEAS imposed on themselves internally binding obligations in respect of the instruments they adopt. For example, the preparation of progress reports is subject to the Commission's own established procedure which might foresee consultations with third countries' governments and stakeholders. Even so, the strictness with which self-imposed procedural or formal requirements apply to measures adopted

\footnotetext{
${ }^{59}$ In his article Schuppert makes reference to international administration in international organization more in general. F. Schuppert, 'New Modes of Governance and the Rule of Law', in M. Zürn, A. Nollkaemper, and R. Peerenboom (eds.), Rule of Law Dynamics: In an Era of International and Transnational Governance (2012), 90, at 107.

${ }^{60}$ M. D'Alberti, 'Diritto Amministrativo e Principi Generali', in M. D'Alberti (eds.) Le nuove mete del diritto amministrativo (2010), at 67.

61 J. Mendes, 'Rule of Law and Participation: A Normative Analysis of Internationalised Rulemaking as Composite Procedures', Jean Monnet Working Paper Series, JMWP 13/13; M. Dawson, 'Soft Law and the Rule of Law in the European Union: Revision or Redundancy?', EUI Working Papers, RSCAS 2009/24.

${ }^{62}$ H. C.H. Hofmann, G.C. Rowe and A.H. Türk, Administrative Law and Policy of the European Union (2013), at 151.
} 
by the Commission would clearly seem a matter of choice, as distinct from externally imposed requirements of public consultation or the satisfaction of comitology obligations in respect of the adoption of binding measures.

In order to start thinking about the features that the principle of legality assumes when the Union develops and implements its action in its wider neighbourhood, two cases decided by the European Ombudsman will be used as starting point. In these two cases the Ombudsman was asked to assess the legality of the exercise of power by the Commission in two fields of external relations. ${ }^{63}$ In the first case the claimant stated that the Commission had not respected its legal obligations in the way it developed the 'National Parks Rehabilitation Project' in Southern Ethiopia. The legal obligations derived from the EU Development policy, the IV Lomé Convention, the OECD guidelines on resettlement, and international human rights agreements. The claimant listed a series of flaws in the way the Commission had implemented the project (e.g. no sufficient attention was given to cultural and social issues, lack of consultation with affected people, etc.). ${ }^{64}$ The second case is an individual complaint against the European Commission for the way it dealt with the human rights clause present in the agreement concluded by the Union and its Member States with the Republic of Vietnam. The complainants alleged that, in face of serious human rights violations by the Republic of Vietnam, the Commission failed to use its power to suspend the Cooperation Agreement with Vietnam. ${ }^{65}$

In both cases the Ombudsman used the same methodological approach in determining whether there was a beach of legality (article 4 European Code of Good Administrative Behaviour). First, the Ombudsman determined the Commission's responsibility and role in both cases by looking at the legal provisions giving power to the Commission. Once he defined the exact responsibility of the Commission in carrying out the European Development Fund (EDF) project and in relation to the nature and scope of the human right clause, it turned to the sources of legal obligations that the Commission has to respect in order not to breach the principle of legality. In the case of the EDF project the Ombudsman checked whether the implementation of the Ethiopian project took due account of: the values that became essential in the EU development policy (i.e. cultural and social values by means of community participation at grass root level); and its consistency with international law (in this case Human Rights Conventions). ${ }^{66}$ In the case dealing with the application of the human right clause the Ombudsman started by analysing the text of the Cooperation Agreement between Vietnam and the Union in order to check if there were any guidelines as to the implementation of the clause. Finding it silent on the matter, the Ombudsman than turned to the Treaty which also did not specify how the human right clause should be implemented. ${ }^{67}$ The absence of binding rules defining the Commission's scope of power under the human right clause did not prevent the Ombudsman from continuing its analysis as to the legality of the inaction by the Commission. On the contrary, he stated that even if the Community legislator seemingly intended to confer large degree of discretion on the Commission for the interpretation and application of the clause, this does not imply a complete

${ }^{63}$ Decision on 26 October 2000 of the European Ombudsman on complaint 530/98/JMA against the European Commission, external relations, breach of Article 4 ECGAB; Decision on 28 June 2005 of the European Ombudsman on complaint 933/2004/JMA against the European Commission, external relations, breach of Article 4 ECGAB.

${ }^{64}$ Decision on 26 October 2000 of the European Ombudsman on complaint 530/98/JMA against the European Commission, external relations, breach of Article 4 ECGAB, 'The Complaint'.

${ }^{65}$ Decision on 28 June 2005 of the European Ombudsman on complaint 933/2004/JMA against the European Commission, external relations, breach of Article 4 ECGAB, 'The Complaint'.

${ }^{66}$ Decision on 26 October 2000 of the European Ombudsman on complaint 530/98/JMA against the European Commission, external relations, breach of Article 4 ECGAB, 'The Decision'.

${ }^{67}$ Decision on 28 June 2005 of the European Ombudsman on complaint 933/2004/JMA against the European Commission, external relations, breach of Article 4 ECGAB, 'The Decision'. 
absence of legal limits. ${ }^{68}$ In this context the Commission has set out some principles for the operationalisation of the human rights clause in its 1995 Commission Communication. Thus, the Ombudsman assessed the legality of the inaction by the Commission against the principles outlined in the 1995 Commission Communication on the application of human rights clauses.

These two Ombudsman decisions raise interesting points for the analysis carried out by this paper. First, the Ombudsman was not prevented from carrying out a legality review by the fact that the Commission's power concerned external relations and was characterised by a large degree of discretion; second, the Ombudsman by reviewing the lawfulness of these activities as possible examples of maladministration categorised them as exercise of administrative power; and finally, he provided an indication of the methodology and the sources needed in order to assess legality of administrative power exercised externally. Assessing legality requires: to first determine the Commission responsibility in exercising a specific power (acting within powers); and second to identify the list of sources aimed at guiding the Commission's power (correct exercise of discretion). To this point it is interesting to notice that the Ombudsman not only requires the Commission to act according to EU primary and secondary law; but also to respect international human rights conventions as well as the values that underline the policy. In this respect we see an attempt by the Ombudsman to overcome the lack of EU internal legislative acts. In both cases the Ombudsman found the action and the inaction of the Commission to be lawful.

This sub-section - as a starting point - will limit itself to identify the list of sources, principles and procedures that can potentially be used to determine if the Union is respecting the principle of legality when developing and implementing its action in its wider neighbourhood. A preliminary analysis of the different sources shaping the formulation of the various instruments developing and implementing the SAP and the ENP highlighted very interesting points. Firstly, all the Commission and EEAS guidelines on how to prepare progress reports, action plans, European Partnerships, strategy papers and programming documents focus on the importance of carrying out consultations - not only with third countries - but also with civil society and stakeholders. ${ }^{69}$ Next to overarching guiding procedures - like guaranteeing a participatory approach - there are principles which are relevant to only one specific typology of instruments. For example, the IPA II Regulation and the ENI Regulation (as well as the relevant Commission and EEAS guidelines on how to develop and implement the financial cycle) stresses the importance that strategy papers and programming documents ensure coherence and consistency with other Union policy. ${ }^{70}$ Another example is the one of the progress

${ }^{68}$ Decision on 28 June 2005 of the European Ombudsman on complaint 933/2004/JMA against the European Commission, external relations, breach of Article 4 ECGAB, 'The Decision'.

${ }^{69}$ European Commission Director General Enlargement, Guidance Note Enlargement Package 2012, Access to documents request GESTDEM Reference 2013/3857; EEAS, Guidance Note ENP Package 2014, Access to Documents request GESTDEM reference 2013/5084; European Commission Director General Enlargement, Instrument for Pre-Accession Assistance (IPA II) Quick Guide to IPA II Programming, Access to Documents request GESTDEM reference 2014/4443; EEAS and European Commission Director General for Development and Cooperation - EuropeAid, Strategic Priorities 2014-2020 and Multi-annual Indicative Programme 2014-2017 European Neighbourhood-wide measures, Access to Documents request SG1 - Corporate Board Secretariat; Council Regulation (EC) No 533/2004 of 22 March 2004 on the establishment of European partnerships in the framework of the stabilisation and association process, OJ L 86/1; EEAS, Non-Paper: Guidelines for Future ENP Action Plan, Access to Documents request SG1 - Corporate Board Secretariat.

${ }^{70}$ Article 5 Regulation (EU) No. 231/2014 of the European Parliament and of the Council of 11 March 2014 establishing an instrument for Pre-accession Assistance (IPA II), OJ [2014] L77/13, article 5 Regulation (EU) No. 232/2014 of the European Parliament and of the Council of 11 March 2014 establishing a European Neighbourhood Instrument (ENI), OJ [2014] L77/30; European Commission Director General Enlargement, Instrument for Pre-Accession Assistance (IPA II) Quick Guide to IPA II Programming, Access to Documents request GESTDEM reference 2014/4443; EEAS and European Commission Director General for Development and Cooperation - EuropeAid, Strategic Priorities 2014-2020 and Multi-annual Indicative Programme 2014-2017 European Neighbourhood-wide measures, Access to Documents request SG1 - Corporate Board Secretariat. 
reports for the SAP countries. The Commission guidelines on how to prepare the reports on the progress made by the countries of the Western Balkans region towards European integration stresses the need to guarantee equal treatment across reports. ${ }^{71}$ The last example is from the ENP action plans. The guideline notice on how to draft action plans indicates the importance of respecting joint ownership, and thus building the action plan in accordance to the partner's reform plan. ${ }^{72}$

\section{Protection of legitimate expectations}

The numerous administrative activities that shape the SAP and the ENP have the potential of creating expectations for third country's individuals. As already mentioned in sub-section 3.2, by adopting administrative instruments the Union increases the predictability of how a certain policy will be implemented, and thus raises the expectations of natural and legal persons as to how a certain policy will be enforced. According to the jurisprudence of the Court of Justice, legitimate expectations are stronger when they are based on a vested right or when the action or inaction of the institutions provoke a significant change on the legal status of the individual. ${ }^{73}$ The realm of external relations makes it very difficult for an individual to prove that the administrative activities carried out by the Union impinges on a vested right or it produces a significant change in their legal status. The jurisprudence of the Court in the field of application of fines in competition cases seems to open a chink for the relaxation of the principle. In its case law the Court stated that the Commission by publishing non-binding instruments informs Member States and individuals on the ways in which it intends to exert its discretion. ${ }^{74} \mathrm{~A}$ departure from the rule of conduct inscribed in the non-binding instruments can breach legitimate expectations. ${ }^{75}$ However, this approach taken by the court seems to remain restricted to the field of application of fines in competition cases. The creation of expectations can be concretely pictured in the three cases dealing with third country citizens that went all the way to the CJEU.

The first case sees as claimant Mr. Muhamad Mugraby, a Lebanese citizen who himself claims to have suffered human rights violations in his home country. ${ }^{76}$ The applicant filed an action for failure to act seeking a declaration that the Commission unlawfully omitted to take a decision on the applicant's request concerning the adoption of measures against the Republic of Lebanon on account of the alleged violations by the latter of the applicant's fundamental rights. The applicant also filed an action for damages seeking compensation for the harm he allegedly suffered as a result of the institutions' failure to act. Mr. Mugraby claims that the Community, the Commission and the Council have incurred non-contractual liability for harm suffered by him as a result of their failure to effectively utilise the available resources and instruments towards effective enforcement of the human right

${ }^{71}$ European Commission Director General Enlargement, Guidance Note Enlargement Package 2012, Access to documents request GESTDEM Reference 2013/3857.

${ }^{72}$ EEAS, Non-Paper: Guidelines for Future ENP Action Plan, Access to Documents request SG1 - Corporate Board Secretariat.

${ }^{73}$ J. Schwarze, European Administrative Law (1992), at 946; H. C.H. Hofmann, G.C. Rowe and A.H. Türk, Administrative Law and Policy of the European Union (2013), at 179.

${ }^{74}$ O. Ştefan, Soft Law in Court: Competition Law, State Aid and the Court of Justice of European Union (2013), at 201.

75 'In adopting such rules of conduct and announcing by publishing them that they will henceforth apply to the cases to which they relate, the institution in question imposes a limit on the exercise of its discretion and cannot depart from those rules under pain of being found, where appropriate, to be in breach of the general principles of law, such as equal treatment or the protection of legitimate expectations. It cannot therefore be precluded that, on certain conditions and depending on their content, such rules of conduct, which are of general application, may produce legal effects.' Joined Cases C-189/02, C-202/02, C-205/02, C-208/02 and C-213/02 Dansk R $\phi$ rindustriand others v. Commission [2005] ECR I-5425, para. 211; see also Opinion Advocate General Bot in Case C-76/06 Britannia Alloys v. Commission [2007] ECR I-4405, para. 142.

${ }^{76}$ Case T-292/09 Mugraby v. Council and Commission; Case C-581/11 P Mugraby v. Council and Commission. 
clause present in the Association Agreement concluded by the European Community and its Member with the Republic of Lebanon ('the Association Agreement'). The available resources being: the suspension of aid granted by the Community to Lebanon in accordance to Article 28 of the ENPI regulations and the suspension of Community aid programs granted under the Association Agreement.

On the 29 April 2009 Mr. Mugraby contacted by letter the Commission in order to suspend the implementation of the on-going economic aid programmes between the Community and Lebanon in view, in particular, of the violation by Lebanon of the clause relating to human rights in article 2 of the Association Agreement. In the same letter the applicant requested the Commission to submit a recommendation to the Council regarding the suspension of Union aid to Lebanon pending the resolution of Lebanon's failures to comply with article 2 of the Association Agreement. Finally, in that letter, the applicant also requested the Council - in its function as part of the EU-Lebanon Association Council - to invite the Commission to recommend that the Council take specific and effective measures regarding the Community aid to Lebanon under the Association Agreement. Within a month the Council informed Mr. Mugraby that it had received his letter and that it had transmitted it to the Presidency of the Council. On the 29 May also the Commission responded to Mr. Mugraby reminding the applicant that the respect for human rights and the reform of the Lebanese judicial system remained high on the European Union-Lebanon bilateral agenda. The Commission also informed the applicant that the procedure to be followed in the case where there is a failure to fulfil one of the obligations imposed on the parties by the Association Agreement is set out in article 86 of the same agreement. Under that provision, if one party considers that the other party has failed to fulfil one of the obligations under the agreement it may take the appropriate measures in accordance with international law. In that regard, the Commission stated that it was not convinced that suspension of the agreement would constitute an appropriate or effective reaction to the applicant's case. Not satisfied with the Commission's and Council reaction to his requests, Mr. Mugraby lodged its application to the Registry of the General Court on 27 July 2009.

There are many interesting points raised by this case, however, the analysis for this sub-section will be limited to what concerns raising expectations. Mr. Mugraby in his application to the Court claimed to have developed:

'strong and legitimate expectations that his fundamental rights would be protected by all the institutions of the European Union, including the courts of law, and that those institutions would hold the parties to the Association Agreement to their obligations. ${ }^{, 77}$ [Emphasis added]

The question to be asked now is: how could Mr. Mugraby even think that he could expect that the Union would suspend its relations with Lebanon due to the violations of human rights by the latter? He claims to have derived his legitimate expectations from the various public statements that the Commission and the Council have made in the context of: the management of the European Union's external policy, the respect of the Association Agreement, and in relation to the protection of human rights. Moreover, he derived his expectations from the Barcelona Declaration on the EuroMediterranean Partnership and article 2 of the Association Agreement. ${ }^{78}$ The Court, however, observed that such assertions are:

'not precise enough to identify, firstly, the conduct complained of with any certainty and, secondly, its possible unlawfulness. In any event, the applicant does not establish how he could acquire a right from those expectations. ${ }^{79}$

\footnotetext{
${ }^{77}$ Case C-581/11 P Mugraby v. Council and Commission, para. 78.

${ }^{78}$ Case T-292/09 Mugraby v. Council and Commission, para. 52.

${ }^{79}$ Case T-292/09 Mugraby v. Council and Commission, para. 71.
} 
The second case sees as applicants 'a coalition of non-governmental organisations and Turkish citizens' ${ }^{80}$ including: Mr. Cemender Korkmaz (residing in Flers), 'Corner House Research' (established in Sturminster Newton), and 'The Kurdish Human Rights project' (established in London). The coalition filed an application for the annulment of the Commission's Regular Report ('the Progress Report') of 5 November 2003 concerning Turkey's progress towards accession, insofar as - according to the applicants - it contains a Commission decision refusing to make a recommendation to the Council concerning pre-accession aid granted to Turkey and, in alternative, for a failure to act in that regard. In other words, the applicants sought the annulment of the progress report because they believed it did not report on a violation by Turkey of its pre-accession obligations; and they believed that if it had done so, pre-accession assistance towards Turkey would be suspended. However, as the Court states, 'it is clear from the applicants' pleadings that they seek the annulment not of the Regular Report as such', ${ }^{81}$ but of a Commission decision refusing to propose to the Council to take appropriate measures concerning the assistance granted to Turkey during the pre-accession period on the grounds that an essential element of continuing entitlement to pre-accession aid is lacking (Article 4 of Regulation No 390/2001).

By letter of 3 July 2003 the coalition called on the Commission to act in connection with 'Turkey's involvement with the Baku-Tbilisi-Ceyhan Pipeline Project' and 'Turkey's breaches of pre-accession criteria'. ${ }^{82}$ The coalition in its letter claimed that Turkey was failing in its obligations as a candidate country for accession to the Union. According to the summary made by the Court in its factual background, the obligations of which the coalition alleged infringement were: making sufficient progress to satisfy the Copenhagen Criteria concerning human rights, respect for and protection of minorities; and adopting the acquis communautaire. ${ }^{83}$ The infringements were connected with the implementation of a project by Turkey for a pipeline linking the cities of Baku, Tblissi and Ceyhan to enable oil to be carried from the Caspian Sea to the Mediterranean (hereinafter 'the BTC project'). Finally, the coalition claimed in the letter that the Commission should, by virtue of its duty to monitor the pre-accession process, penalise those infringements by proposing to the Council that it should take appropriate steps against Turkey under the Accession Partnership legislation and to recommend that all pre-accession assistance be frozen until modification or cessation of the BTC project and in the meantime that 'all further accession negotiations with Turkey be suspended. ${ }^{84}$ On the 4 August 2003 an official of the Commission Directorate General for Enlargement replied to them sating that the Commission have taken note of the points they raised about Turkey's involvement in the [BTC] Project. However, since Turkey is not yet a member of the European Union and accession negotiations are not yet opened, one cannot conclude at this stage that Turkey is in breach of any EU law or of its accession obligations. Nevertheless, Turkey by being a candidate country has undertaken to comply with the EU accession criteria, including the political criteria on democracy, the protection of human rights and of minority rights. Therefore, any human rights or national minority rights violations arising from the implementation of the [BTC] Project would have to be seen in the context of the Copenhagen political criteria. The letter of the Commission concludes that it will continue to follow closely the developments in Turkey surrounding this case and give an assessment of the human rights and minority rights situation in its Regular Report in November [2003] ${ }^{85}$ Subsequently, the coalition on of 2 September 2003 noted that the Commission's assurance that it will investigate and report on the developments in Turkey surrounding this case in its November 2003 Regular Report is not an

\footnotetext{
${ }^{80}$ Case T-346/03 Krikorian v. European Parliament, Council and Commission, para. 11.

${ }^{81}$ Case T-346/03 Krikorian v. European Parliament, Council and Commission, para. 34.

${ }^{82}$ Case T-346/03 Krikorian v. European Parliament, Council and Commission, para. 13

${ }^{83}$ Case T-346/03 Krikorian v. European Parliament, Council and Commission, para. 13.

${ }^{84}$ Case T-346/03 Krikorian v. European Parliament, Council and Commission, para. 14.

${ }^{85}$ Case T-346/03 Krikorian v. European Parliament, Council and Commission, para. 15.
} 
adequate response to the necessary measures on pre-accession finance. They therefore 'urged the Commission again to take urgent action' by adopting the measures requested on 3 July 2003. The Commission again replied by stating that it will continue to follow closely the developments concerning the [BTC] project and where necessary evaluate the consequences in light of the Copenhagen political criteria. On 5 November 2003, the Commission adopted its Regular Report on progress made by Turkey towards accession which is the one subject to application for annulment in the case under discussion.

Admittedly the vision of the applicants was distorted as to the decision making process of the Union when it comes to suspension of financial aid. Nevertheless, the core of the dispute lies in the frustration on the side of the coalition not to have seen their views taken seriously. The coalition had the expectation that the Commission by virtue of its duty to monitor the pre-accession process would conduct more adequate research in the allegations they made. The applicant do not succeed either in their claim for annulment or in their claim for failure to act.

The third case is a bit different from the previous two; it deals with an action for compensation lodged by a Turkish company Yedaş Tarim ve Otomotiv Sanayi ve Ticaret AŞ ('Yedaş Tarim') for damage allegedly caused by the implementation of the procedures of the Customs Union instituted by the Association Agreement between the European Economic Community and Turkey. ${ }^{86}$ The applicant among different allegations of unlawful conduct by the Community in respect of the implementation of the Custom Union, ${ }^{87}$ states that 'the Community failed to honour an undertaking to give Turkey financial support of 2.500 million'. That undertaking was allegedly given at the meeting of the ECTurkey Association Council. Furthermore, the applicant claims that, in the context of the EuroMediterranean cooperation, promises of aid were made which have not been honoured. The Court turns down the applicant's claims since it is not precise enough in identifying the conduct complained of, its possible unlawfulness, and the applicant does not establish how individuals could acquire right under those promises. ${ }^{88}$ However, again in this case we are presented with an individual that derives its expectations by the numerous activities characterising the policy of the Union towards Turkey. Differently from the other two cases, there was no direct contact between Yedaş Tarim and the Commission or the Council.

These three cases clearly show that the activities aimed at implementing the Union's policies with its neighbours are not neutral. They do create expectations. These expectations might not be defined as 'legitimate expectations' under EU law, however, they cannot simply be ignored. If the protection of legitimate expectations under the current Treaties and jurisprudence of the court does not seem to offer a platform for the protection of expectation being raised by the activities carried out by the Commission - and only recently the EEAS - in implementing the SAP and the ENP; how can we still try to enforce this principle under the new obligation that the Union has to respect the rule of law when developing and implementing its external action? A possible solution would be to identify certain procedural requirements that the Commission and the EEAS need to respect when directly contacted by individuals under the principle of legality or possibly good administration. Is it possible to affirm that the Commission's responses to Mr. Mugraby and the coalition of Turkish were adequate? Was their response complete? Were they precise? Did they really take seriously the applicant's claims? Were the applicants granted the possibility to fully explain their concerns? The judge only arrives at the last instance. The process that leads an individual to decide whether or not he

\footnotetext{
${ }^{86}$ Case T-367/03 Yedaş Tarim ve Otomotiv Sanayi ve Ticaret AŞv. Council of the European Union and Commission of the European Communities.

${ }^{87}$ Case T-367/03 Yedaş Tarim ve Otomotiv Sanayi ve Ticaret AŞv. Council of the European Union and Commission of the European Communities, para. 22.

${ }^{88}$ Case T-367/03 Yedaş Tarim ve Otomotiv Sanayi ve Ticaret AŞv. Council of the European Union and Commission of the European Communities, para 47-48.
} 
or she will make use of the judiciary represents a first important step in guaranteeing the protection of individual interests and expectations.

For the sake of completeness, before concluding this section on protection of legitimate expectation, two final hypothetical examples of how administrative activities carried out in the EU wider neighbourhood can raise expectations will be presented. The first example stems from the ability of action plans to carry out an interpretative function. Action plans can - under certain circumstances flesh out the scope and substance of the underlying international agreements. ${ }^{89}$ Action plans are adopted as 'recommendations' on how to implement the agreements concluded by the Union with its neighbours and as instruments aimed at enhancing the relation between the Union and its neighbouring states. Insofar as they work as recommendations on how to implement the agreement, their text uncovers some details as to the content of the latter. Van Vooren in his article on the use of soft law in the European Neighbourhood Policy discusses in detail, by using as starting point the Deutsche Shell case,${ }^{90}$ how action plans can interpret individual rights stemming from the agreements concluded by the Union with its neighbours. ${ }^{91}$ One of the examples he outlines becomes relevant for the analysis of this paper. The hypothetical example goes as follows and refers to the previous agreement concluded between the EU and Ukraine. If a Ukrainian subsidiary goes into default in a Member State, and that bankruptcy laws differentiate according to whether the mother company is established in or outside the Union/EEA, article 30(1)(b) of the PCA with Ukraine would be relevant:

"(b) Without prejudice to the reservations listed in Annex IV, the Community and its Member States shall grant to subsidiaries of Ukrainian companies established in their territories a treatment no less favourable than that granted to any Community companies, in respect of their operation, and this in conformity with their legislation and regulations."

However, if a dispute would arise over the rules that pertain to the 'operation of companies', namely whether bankruptcy rules are included in its scope, the action plan with Ukraine can be useful to resolve the dispute insofar as it clarifies the meaning of the article by specifying that these rules include 'competition and bankruptcy legislation' ${ }^{92}$ In this context, it is possible to state that action plans can give rise to legitimate expectations to the extent that they can inform individuals of the rights they can derive from the agreement concluded by the EU with their own country.

The last and final example of how legitimate expectations can be created can be found in how the cycle for financial assistance is implemented. Strategy papers [as already explained above] define the priorities for action towards meeting the objectives identify by the financial assistance regulation, the progress reports, the action plans and the European partnerships; and also indicate how assistance will be provided (i.e. through twinning, technical assistance, etc.). They cover a six year period and thus allow potential organisations, companies, NGOs, etc. to prepare projects in line with the strategy papers. Therefore, potential receivers of financial assistance will develop expectations that the strategy paper will be followed by the Commission when preparing programming documents.

\footnotetext{
${ }^{89}$ B. Van Vooren, 'A case-study of soft law in EU external relations: the European Neighbourhood Policy', European Law Review 2009, 34(5).

${ }^{90}$ Case C-188/91, Deutsche Shell AG v Hauptzollamt Hamburg-Harburg, [1993] I-363, paras 17-18.

${ }^{91}$ B. Van Vooren, 'A case-study of soft law in EU external relations: the European Neighbourhood Policy', European Law Review 2009, 34(5).

92 B. Van Vooren, 'A case-study of soft law in EU external relations: the European Neighbourhood Policy', European Law Review 2009, 34(5).
} 


\section{Judicial Review}

The idea that the administration should be procedurally and substantively accountable before the courts is a cornerstone principle stemming from the rule of law and it gives teeth to legality and protection of legitimate expectations. ${ }^{93}$ According to the Court, judicial review of measures adopted by the Union institutions is guaranteed by the complete system of legal remedies and procedures established by the Treaties. ${ }^{94}$ Two are the main ways of making the Union administration accountable before the courts. First, the Treaties offer the opportunity to challenge the action or inaction of the Union administration. Natural and legal persons - as well as Union institutions and Member States can challenge the action or inaction of the Union administration by filing an application for failure to act (article 265 TFEU); or alternatively, the Union has the obligation to make good any damage caused by the action or inaction of its institutions or by its servants in the performance of their duties (article 340 TFEU). Second, the Treaties provide the possibility of challenging the legality of acts of the administration (article 263 TFEU). However, in order for the principle of judicial review to be upheld, access to court needs to be guaranteed by this same system of legal remedies and procedures. In other words, access to court is an indispensable variable in order to guarantee judicial review. Therefore, it becomes important to focus the analysis on judicial review from the point of view of access. Can a legal or natural person challenge the administrative activities that aim at developing and implementing the SAP and the ENP? Would the European Parliament be in a better position to challenge the measures? Are there obstacles on the way to effective judicial review? The obstacles on the way are numerous, however, they should not limit the analysis; on the contrary they shall start a debate.

In the first two cases discussed in the previous sub-section on protection of legitimate expectations, the applicants challenged the inaction of the Commission. The applicants believed that the Commission was under an obligation to suggest to the Council to suspend the relations between the Union and their respective countries: Lebanon and Turkey. The application by the 'coalition of civil society and Turkish citizens' is quite peculiar since they seek the annulment of the decision refusing to propose to the Council to take appropriate measures against Turkey for failure by the latter to comply with its pre-accession obligations. In this case the inaction of the Commission is not reviewed since the refusal cannot be regarded as producing binding legal effects capable of affecting the applicants' interests by bringing about a significant change in their legal position. However, interestingly enough, the CFI in this case stated clearly that:

'individuals are not deprived of access to the courts by reason of the fact that a measure not producing binding effects capable of affecting their interests by bringing about a significant change in their legal position cannot be the subject of an action for annulment, an action to establish non-contractual liability provided for in Article $235 \mathrm{EC}$ and the second paragraph of Article $288 \mathrm{EC}$ being available to them if such a measure is capable of causing the Community to incur liability. ${ }^{95}$ [Emphasis added]

Mr. Mugraby - in a comparable situation - filed an action for failure to act and an action for noncontractual liability against the inaction of the Commission. Nevertheless, he also failed to obtain judicial review of the inaction of the Commission since the exercise of Commission discretion excludes a right for an individual to require the Commission to take a position. ${ }^{96}$ An action for failure to act is only available when the failure to adopt a measure produces binding legal effects capable of

\footnotetext{
${ }^{93}$ P. Craig, EU Administrative Law (2012), at 251.

${ }^{94}$ Case 294/83 Les Verts v. Parliament [1986] ECR 1339, para. 23.

${ }^{95}$ Case T-346/03 Krikorian v. European Parliament, Council and Commission, para. 55.

${ }^{96}$ Case T-292/09 Mugraby v. Council and Commission, para. 38 and para. 61.
} 
affecting the interests of the applicants by bringing about a distinct change in their legal position. ${ }^{97}$ Non-contractual liability is only available when there has been a 'sufficiently serious breach of a rule of law intended to confer rights on individuals ${ }^{98}$ and again, the article foreseeing the possible suspension of the agreement concluded by the Union with Lebanon does not confer rights on the individuals.

If natural and legal persons cannot obtain review of the inaction of the Commission, how can the Commission's decision not to act be reviewed? As the Ombudsman stated in the case dealing with Vietnam, even if the Commission enjoys a wide margin of discretion in this type of situations, this does not imply that the discretion is not subjects to some limits. ${ }^{99}$ The Ombudsman in the case dealing with the suspension of the agreement concluded by the Union with Vietnam did review the Commission decision not to act by checking whether it complied with the guidelines that the Commission imposed on itself as to when to trigger the application of the human rights clause. The CJEU did not conduct the same review when approached by the "coalition of civil society and Turkish citizens' and by Mr. Mugraby. The obstacle on the way to obtain judicial review of the Commission inaction was the lack of direct and individual concern and the lack of right on the side of individuals to see an agreement between the Union and a third country suspended.

Let's now turn to the possibility of reviewing the legality of the different administrative measures constellating the SAP and the ENP. If a natural or legal person would want to review a progress report the obstacle on the way would be of two types. The first is the lack of reviewability. Progress reports do not belong to any category of acts as listed in article 263 TFEU and they do not have binding force vis-à-vis third parties. The second, - in case of non-privileged applicants - is the need to show direct and individual concern. The role of non-binding instruments and the need for their judicial review is increasingly becoming a topic of debate within the EU internal realm. In fact, even if the European Court privilege substance over form in deciding which measures may be challenged, there are still reasons to be concerned. Scott, for example, in one of her articles shows how post-legislative guidelines - despite their practical impact on Member States - too often escape judicial review. ${ }^{100}$ The very recent Advocate General Opinion in the OMT case seems to open the door for a new approach as to the reviewability of acts not creating binding effects towards third parties. The Advocate General in his opinion seems to suggest that general action programmes of public authorities may take atypical forms and yet still be capable of having a very direct impact on the legal situation of individuals. The addressee and type of the measure loses importance, what becomes relevant is the ability of the programme to have an impact on the legal situation of third parties. Beside the objective aspect, the AG also suggests a contextual approach.

'The context in which an act is adopted may provide further indications which confirm either the author's intention that the act should produce effects vis-à-vis third parties or the fact that the author was aware of the potential external impact of the measure. ${ }^{101}$ [Emphasis added]

\footnotetext{
${ }^{97}$ Case T-292/09 Mugraby v. Council and Commission, para. 38 and para. 61; Case T-346/03 Krikorian v. European Parliament, Council and Commission, paras 38-39.

${ }^{98}$ Case T-292/09 Mugraby v. Council and Commission, para. 55.

${ }^{99}$ Decision on 28 June 2005 of the European Ombudsman on complaint 933/2004/JMA against the European Commission, external relations, breach of Article 4 ECGAB, 'The Decision'.

${ }^{100}$ See: J. Scott, 'In Legal Limbo: Post-Legislative Guidance as a Challenge for European Administrative Law', Common Market Law Review 48: 329, 2011, at 344.

${ }^{101}$ Opinion of Advocate General Cruz Villalón delivered on 14 January 2015, Case C-62/14 Peter Gauweiler, Bruno Bandulet, Wilhelm Hankel, Wilhelm Nölling, Albrecht Schachtschneider, Joachim Starbatty, Roman Huber and Others, Johann Heinrich von Stein and Others, and Fraktion DIE LINKE im Deutschen Bundestag v Deutscher Bundestag, para. 80.
} 
This new approach taken by the AG could be very well suited in order to draw a comparison with progress reports and the commission communication on the implementation of the SAP and the ENP. It is undeniable that the authors' intentions behind the different activities characterising the Union wider neighbourhood is that of producing effects vis-à-vis third parties. This approach could - at least - push the European Parliament to challenge the legality of Progress Reports. Natural and legal person would still have to prove direct and individual concern.

The reviewability of action plans and European Partnerships faces a less onerous obstacle when compared to progress reports. They are adopted internally as Council Decisions, thus, they are acts whose reviewability can be challenged under article 263 TFEU. Natural and legal persons are again faced with the obstacle that they need to prove direct and individual concern. However, privileged applicants, like the European Parliament, are not prevented from challenging their legality. However, the main final challenge for the reviewability of progress reports, action plans and European Partnership is to identify against which rules of law or essential procedural requirement their legality can be reviewed. The analysis provided by this paper in the sub-section titled 'legality' could represent a starting point. Lastly, the obstacles on the way of guaranteeing the reviewability of strategy papers and programming documents by natural and legal persons will depend on the interpretation of the term 'regulatory acts' found in article 263 TFEU. If strategy papers and programming documents would fit the category of regulatory act not entailing implementing measures; than individuals will only have to prove direct concern in order to require to the Court to review the legality of those measures.

Finally, when analysing the principle of judicial review it is also important to bear in mind that the judge arrives only at the last stage. The reviewability of Union's activities and the protection of individual rights can be guaranteed also throughout the process of adoption of the specific act. Procedural guarantees, like participation, ${ }^{102}$ are themselves a first step in guaranteeing that the interested parties will not be adversely affected by a Union decision. This should be particularly the case in light of the difficulties faced by individuals to obtain access to judicial review.

\footnotetext{
${ }^{102}$ The literature on participation right has so far focus only to the internal policy of the Union. J. Mendes, 'Participation and participation rights in EU law and governance', in H.C.H. Hofman, and A.H. Türk, Legal Challenges in EU Administrative Law: Towards an Integrated Administration (2009), 257-287.
} 


\section{Conclusion}

While the most dramatic acts of formal international governance may be the adoption of major global treaties, or the taking of a high political decisions in the European Council or the Foreign Affairs Council concerning 'war and peace', much of the activity which directly affects individuals, groups, corporations, and third States is the more routine work done by the Commission and the EEAS. These routine acts of governance, even if apparently less dramatic, are nevertheless very significant: they may be treated as authoritative by the third state and they may influence their attitude and behaviour. Therefore, it becomes more and more important to question how the EU interacts with the outer world and to have control over the power exercised by the Union administration when developing and implementing the Union's external action. This becomes even more relevant now that the Lisbon Treaty reiterates that the rule of law shall structure the relations between the Union and the outer world. The conflict between how the Union develops its external net of activities and the rule of law is real, and it should not simply be ignored by referring to the external action of the Union as a parallel structure to the internal one governed by the EU's funding principles. This paper has shown that the presence of this conflict should not lead us to dismiss the 'Rule of Law'; instead it merits a more attentive analysis as to what it means to respect the rule of law in the realm of external relations.

With this aim in mind this paper has made the following points. First, the rule of law is a constitutional principle that needs to be respected when the Union acts externally. Second, that in order to give substance to this obligation and to make it justiciable it is essential to fully understand its significance. To understand the meaning of the rule of law, this paper looked at how the principle has been constructed internally. Finally, by using as a starting point the internal definition, the paper turned to the applicability of this definition to the external domain. In order to operationalise the respect of the rule of law when the Union acts in its wider neighbourhood, it is essential to identify and give substance to the sub-principles giving effect to the rule of law.

The final part of the paper sets the ground for a new research agenda by showing how principles giving effect to the rule of law internally encounter specific obstacles and challenges when 'dipped' in the realm of the Union external relations. The analysis carried out by this paper for each principle giving effect to the rule of law (i.e. legality, legitimate expectations and judicial review) used as starting point not only the meaning that each principle has internally but also their application by the Ombudsman and the CJEU in concrete cases dealing with activities carried out by the Union in its external action. This type of analysis highlighted the obstacles on the way of guaranteeing the effective application of each principle in practice. The paper has, thus, tentatively suggested some possible solutions in order to still give effect to the principles despite the obstacles. Thinking of ways in which the principles giving effect to the rule of law can effectively operate is the starting point in order to evaluate the current legal framework and to guarantee the protection of the rule of law when the Union acts externally. 
